\begin{tabular}{|c|c|}
\hline & Volume \& Issues Obtainable at The Women University Multan \\
& Annals of Social Sciences and Perspective \\
& ISSN: 2707-7063, Volume 2, No.2 December 2021 \\
\end{tabular}

\title{
Role of Female Labor Force Participation in Child Health
}

\section{Mabrooka Altaf ${ }^{1}$,Tusawar Iftikhar Ahmad ${ }^{2}$, Muhammad Azhar Bhatti $^{3}$}

${ }^{1}$ Ph.D. Scholar, Department of Economics, The Islamia University of Bahawalpur, Pakistan

${ }^{2}$ Assistant Professor, Department of Economics, The Islamia University of Bahawalpur, Pakistan ${ }^{3}$ Associate Lecturer, Department of Economics, The Islamia University of Bahawalpur, Pakistan

ARTICLE DETAILS ABSTRACT

$\begin{array}{ll}\text { History: } & \\ \text { Received: } & \text { December 10,2021 } \\ \text { Review: } & \text { December 21, 2021 } \\ \text { Accepted: } & \text { December 28, 2021 } \\ \text { Available Online: } & \text { December 30,2021 }\end{array}$

\section{Keywords:}

Female Labor force Participation

Child Immunization

Mother's Education

Woman Empowerment

Household Poverty

\section{DOI:}

10.52700/assap.v2i2.119

The objective of the study is to investigate the impact of female labor force participation on child (under 5-years of age) health in Pakistan. Child health was gauged through child immunization coverage status measured by recording receipt of 22 doses of eight basic vaccines. A micro data set (i.e., 5872 children) from Pakistan Demographic Health Survey (PDHS) 2017-2018 was utilized for the study. As per recommendations of the World Health Organization, if a child had received all the 22 doses of those eight important vaccinations, helshe was assumed as highly immunized, and vice versa. The impact of mothers' employment and other explanatory variables, on child health, was investigated using Ordered logistic regression. The child with higher birth $\operatorname{order}(O R=0.927 ;$ p-value $=0.000)$, the child of not-working mother $(O R=0.829$; $p$-value $=0.012)$, the child of illiterate mothers $(O R=0.606 ; p$-value $=$ 0.000), the child of the mother having no own mobile phone $(O R=0.793 ;$ p-value $=0.000)$, and the child belonged to the poorest family $(O R=0.535$; $p$-value $=$ $0.000)$ had less likelihood of immunization coverage. Mother's age $(O R=1.055$; $p$-value $=0.005)$, number of $A N C$ visits made by the mother $(O R=0.925 ; p$-value $=$ $0.000)$, and male gender of the child $(O R=1.086 ; p$ value $=0.082$ ) had more probabilities for child immunization coverage. Hence, there is a need to alleviate poverty and gender discrimination as well as to create opportunities to increase female education, awareness, and labor force participation for better outcomes relating to child health.

(C) 2021 The Authors, Published by WUM. This is an Open Access Article under the Creative Common Attribution Non Commercial 4.0

Corresponding author's email address: mabrookabaloch@yahoo.com

\section{Introduction}

Pakistan is the world's 36th largest country by area, with a population of 207.8 million people (Lee et al. 2019 \& PBS 2017). The 'Expanded Program on Immunization was established in 
Pakistan in 1978 with the purpose of preventing children under the age of one year from infectious diseases such as fever, cough, etc. Children's immunization may help to reduce morbidity and death rate. As per recommendations of WHO, at the time of birth, a child should receive one dose of BCG vaccine and one dose of poliovirus vaccine, in six weeks of birth, a child should receive three doses of DPT vaccine, and at the ninth month, one dose of measles vaccine should be received by a child (PDHS 2017-18).

Table 1: WHO Recommendations for Child Immunization

\begin{tabular}{|c|c|c|c|c|}
\hline No. & Vaccines & Doses & Time of dose & Prevents from \\
\hline 1. & $\begin{array}{l}\text { BCG } \\
\text { (bacilleCalmette- } \\
\text { Guerin) }\end{array}$ & 1 dose & At Birth & Tuberculosis (TB) \\
\hline 2. & $\begin{array}{l}\text { DPT } \\
\text { (Diphtheria, } \\
\text { Pertussis } \\
\text { Tetanus) }\end{array}$ & 3 doses & $\begin{array}{l}\text { DPT 1: } 6 \text { weeks } \\
\text { DPT 2: } 10 \text { weeks } \\
\text { DPT 3: } 14 \text { weeks }\end{array}$ & $\begin{array}{l}\text { Diphtheria, } \\
\text { (Whooping } \text { Cough), and } \\
\text { Tetanus }\end{array}$ \\
\hline 3. & POLIO & 4 doses & $\begin{array}{l}\text { Polio 0: } 2 \text { months } \\
\text { Polio 1: } 4 \text { months } \\
\text { Polio 2: } 6-18 \text { months } \\
\text { Polio 3: } 4-6 \text { years }\end{array}$ & Poliomyelitis (Polio) \\
\hline 4. & Hepatitis B & 3 doses & $\begin{array}{l}\text { B1: at birth } \\
\text { B2: } 6 \text { months } \\
\text { B3: } 6 \text { months }\end{array}$ & Liver infection \\
\hline & Measles & 2 doses & $\begin{array}{l}\text { Dose 1: } 12-15 \\
\text { months } \\
\text { Dose 2: } 4-6 \text { years }\end{array}$ & Measles (chickenpox) \\
\hline 6. & Pentavalent & 3 doses & $\begin{array}{l}\text { Dose 1: } 6 \text { weeks } \\
\text { Dose 2: } 10 \text { weeks } \\
\text { Dose 3: } 14 \text { weeks }\end{array}$ & $\begin{array}{l}\text { Diphtheria, Tetanus, } \\
\text { Pertussis (Whooping } \\
\text { Cough), Hepatitis B and } \\
\text { HaemophilusInfluenzae } \\
\text { Type B (DTP-Hepb-Hib) }\end{array}$ \\
\hline & Pneumococcal & 3 doses & $\begin{array}{l}\text { Dose 1: } 2 \text { months } \\
\text { Dose 2: } 4 \text { months } \\
\text { Dose 3: } 6 \text { months }\end{array}$ & Pneumococcal \\
\hline 8. & $\begin{array}{l}\text { HIB } \\
\text { (Haemophilus } \\
\text { Influenza Type B) }\end{array}$ & 3 doses & $\begin{array}{l}\text { Dose 1: } 2 \text { months } \\
\text { Dose 2: } 4 \text { months } \\
\text { Dose 3: } 6 \text { months } \\
\end{array}$ & $\begin{array}{l}\text { Bacterial Infection } \\
\text { (Sneezing, Coughing) }\end{array}$ \\
\hline
\end{tabular}

(Source: Pakistan Demographic and Health Survey 2017-18)

These vaccines are registered on a health-care department-issued prescription card. However, according to UNICEF, in Pakistan about $40.6 \%$ children are not fully immunized. 


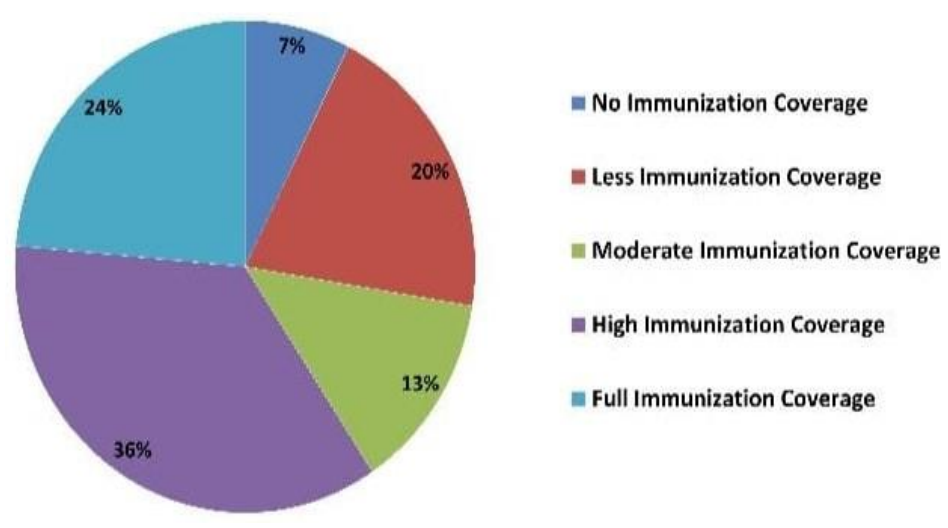

Figure: Child Immunization Coverage Status in Pakistan (Source: PDHS-2018; Authors' Own Calculations)

In LMICs, maternal characteristics, as well as other socioeconomic and demographic characteristics, play a crucial role in improving the health of children (Lee et al. 2019; Asif et al. 2019; Acharya et al. 2018). Moreover, factors such as the use of mass communication and place of residence also have an impact on immunization coverage of children (Acharya et al. 2018). Existing literature showed that maternal employment and education have a significant and positive effect on the health outcomes of the family through the balance of power and benefits through vaccination (Lee et al. 2019). However, several investigations have revealed insignificant effects (Robert et al. 2014) while some studies revealed a negative impact on family health outcomes due to less time available for mothers for feeding and other caregiving activities (Engle et al. 1999; Lavy et al. 1996). Moreover, the reason for the negative impact may be that employed mothers may belong to a male dominated society which limits the maternal power in the household and which will increase the stress and they cannot take care of themselves as for their children (Hindmarsh et al. 2017). So, there is a need to explain the significance of maternal employment to better health care of their children in LMCs countries i.e. Pakistan. Furthermore, these conflicting facts may have emphasized the need for additional research in these areas.

One of the Sustainable Development Goals to be achieved by 2030 is to improve the health of children. Pakistan failed to fulfill its targets of 52 deaths in children and 40 infants' deaths per 1000 live births, but it made some progress. Vaccines, hence, have the potential to contribute significantly to the accomplishment of the health-related SDGs (Duclos et al., 2009).

Table 2: Sustainable Development Goals achieving through Immunization

\begin{tabular}{cll}
\hline No. & Sustainable Development Goals & \multicolumn{1}{c}{ Achieving Through Immunization } \\
\hline 1. & No Poverty & $\begin{array}{l}\text { Healthy Children \& Families = Increased } \\
\text { Prosperity }\end{array}$ \\
\hline 2. & Zero Hunger & $\begin{array}{l}\text { Immunization }+ \text { Nutrition }=\text { Healthier } \\
\text { Families }\end{array}$ \\
\hline 3. & Good Health and Well Being & Immunization = Healthy Lives \& Well-Being \\
\hline
\end{tabular}

Although different studies had investigated the child vaccination coverage in Pakistan (Imran et al. 2018; Khan et al. 2017; Zaidi et al. 2014), but the influence of eight different 
vaccinations at the same time had received no attention. In health economics, child immunization, captured by 22 doses of 8 different vaccines is rarely analyzed. So, using the ordered Logistic Regression modeling technique, this study is intended to contribute to the literature by finding child immunization coverage and factors affecting vaccination uptake in Pakistan. After the introduction in section I, the literature review is discussed in section II, theoretical framework and methodology are explained in section III. Section IV contains the findings and discussion., while the conclusion and policy suggestions are given in section V.

\section{Literature Review}

There is a substantial amount of research that shows a link between a mother's employment and her child's health outcomes. Child health is measured in different studies as hospitalization, injury or poisoning, asthma episode, vaccination and overweight, while child nutrition in different studies is taken as; breakfast, snack, dinner, meal speed, meal portion and healthy eating index (HEI), BMI, dietary intakes, stunting, wasting, underweight and feeding practices of mothers. While mother's employment in different studies is measured as part time/full time employment, formal/informal sector employment, employed/unemployed, reproductive/productive work. Results for developed countries showed that overall, working mothers, whether full time/part time, have less favorable nutritional patterns for their children's growth (Mindlin et al., 2009; Gaina et al., 2009; Crepinsek \& Burstein, 2004). While, in developing countries, the empirical results of the research on working mothers and their children's health outcomes have been quite mixed i.e. insignificant in some studies (Boyle et al., 2018; Potocka \& Jacukowicz, 2017), while some studies found a positive association between women employment and child health (Oddo \& Ickes, 2018; Onah, 2020; Yaya et al., 2020; Wasswa. 2019; Komatsu et al., 2018; Garti et al., 2018; Burroway, 2017; Kabir, 2016; JAMAL, 2018; and some found a negative association between working mothers and their children's health outcomes in developing countries (Kim, 2020; BraunerOtto et al., 2019; Nankinga et al., 2019; Rashad \& Sharaf, 2019; Rao et al., 2019; JAMAL 2018). Child health in different studies, measured with different proxies. To the best knowledge of the authors, none of the earlier studies measured child health as 22 doses of eight different vaccines in the same study. As a consequence, the primary purpose of this research is to determine how women's employment affects the 8 basic vaccination uptake of their children, in Pakistan.

\section{Theoretical Framework}

A variety of theoretical models exist (in literature) in relation to health-care and its implications i.e. Grossman (1972) proposed that medical-care demand be based on demand for good health, the behavioral model for health-care was introduced by Andersen and Newman in 1973, quality aspect of demand-care was introduced by Donabedian (2005) and mother level indicators, pollution of the environment, food inadequacy, injury, and personal sickness control are the five biological and medical proximate drivers of child death proposed by Mosley and Chen (1984). Individual factors, parental features, demographic characteristics, socioeconomic qualities, and geographical characteristics are all distant determinants of child mortality that work through proximate determinants. Instead of using the same as child mortality, we employed the modified proximal determinants approach for immunization of children, which is utilized in several health economics researches (Pande, 2003; Khan and Raza, 2013; Khan and Raza, 2014). 
Theoretical underpinnings of the current study are embedded in the healthcare services utilization model proposed by Andersen and Newman (2005). The description of the model is given below.

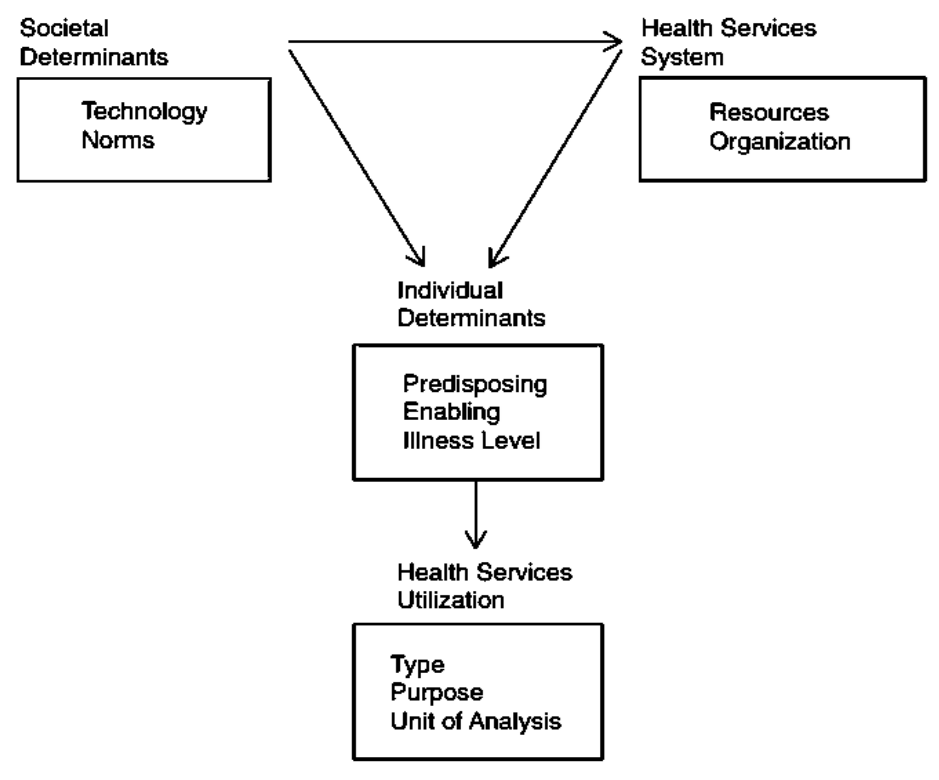

Figure: Healthcare Services Utilization Framework (Andersen and Newman, 2005)

Figure 1 exhibits how the main components of the framework. According to the framework, the amount of health services used by a person is determined by: (1) the predispositionbased on demographic (for example age, gender, and marital status), as well as social determinants (such as education, family size, occupation, religion), and attitudinal or belief related characteristics of the persons to make use of services; (2) enabling characteristics (like household income, health insurance coverage, or another source of third-party payment, accessibility to source) which permit to satisfy a need relating to health service utilization; (3) his illness level factors.

\section{Data and Methodology}

\subsection{Source of Data}

For estimating the child immunization in Pakistan, with respect to women labor force participation, PDHS 2017-2018 data were used to construct this analysis. The PDHS data set includes a variety of mothers and their children's health information and is part of an international demographic, socioeconomic, and health survey system designed to help less developed economies collect data on family planning, reproductive health, maternal and child health, nutrition, immunization, education, and employment. Using two-stage stratified sampling process, a sample of 16, 240 individuals from 561 primary sampling units were selected. From these households, a total of 12,708 women between the ages of 15 and 49 were successfully surveyed. However, this study's analysis was restricted to 5872 live-born children aged one to five years. Child immunization status is determined by 8 basic vaccines i.e. BCG, DPT, Polio, Measles, Pentavalent, Pneumococcal, Hepatitis (B1, B2, B3) and HIB $(1,2,3)$. If a child has received all 22 doses of these 8 vaccinations, he or she is considered highly immunized. The following is a general model of child immunization status:

Child Immunization Status = f (Child level Characteristics, Mother level Characteristics, Household level Socioeconomic Characteristics, Regional level Characteristics)

The following is the functional form of analysis: 
Child Immunization Status $=\mathrm{f}$ (Gender of Child, Birth Order of Child, No. of Children Age 5 and Below, Mother's Education, Mother's Occupation, Mother Own a Mobile Phone, Mother's Age, Number of Antenatal Care Visits, Wealth Index, Place of Residence)

Table 3 shows the operational definitions of the variables.

Table 3: Operational Definition of Variables

\begin{tabular}{|c|c|}
\hline Variables & Definitions \\
\hline \multicolumn{2}{|l|}{ Dependent variable } \\
\hline IMMUN & $0=$ No Immunization Coverage \\
\hline (Child Immunization Status) & $1=$ Less Immunization Coverage \\
\hline & $2=$ Moderate Immunization Coverage \\
\hline & $3=$ Full Immunization Coverage \\
\hline & 4= High Immunization Coverage \\
\hline \multicolumn{2}{|l|}{ Independent Variables } \\
\hline \multicolumn{2}{|l|}{ Individual Characteristics } \\
\hline CGEN (Gender of Child) & 1 for Male, 2 for Female \\
\hline BORD (Birth-Order of Child) & Taken as Continuous. \\
\hline NCHU (No. of Children Age 5 and Below) & Taken as Continuous. \\
\hline \multicolumn{2}{|l|}{ Mother Characteristics } \\
\hline MEDU (Mother's Education) & $\begin{array}{l}0 \text { for Illiterate, } 1 \text { for Primary, } 2 \text { for } \\
\text { Secondary, } 3 \text { for Higher }\end{array}$ \\
\hline MOCCU (Mother Occupation) Binary & $\begin{array}{l}0=\text { Not Working } \\
1=\text { Working }\end{array}$ \\
\hline MOWN (Mother Own A Mobile Phone) & 0 For No, 1 For Yes \\
\hline MAGE (Mother Age) & Taken As Continuous. \\
\hline ANCV(Antenatal Care Visits) & Taken As Continuous. \\
\hline \multicolumn{2}{|l|}{ Socioeconomic Characteristics } \\
\hline WINDX (Wealth Index) & $\begin{array}{l}1 \text { for Poorest, } 2 \text { for Poorer, } 3 \text { for Middle, } 4 \\
\text { for Richer, } 5 \text { for Richest }\end{array}$ \\
\hline \multicolumn{2}{|l|}{ Regional Characteristics } \\
\hline PRES (Place of Residence) & 1 for Urban, 2 for Rural \\
\hline
\end{tabular}

\subsection{Construction of Variables}

The majority of the variables are used in the analysis as given in the survey but some of them need explanation.

\subsubsection{Measuring Immunization of Children}

Child immunization status is a dependent variable and data on vaccination uptake is taken for eight serious diseases - tuberculosis, diphtheria, whooping cough (pertussis), tetanus, polio, measles, liver, and Pneumococcal. In Pakistan twenty-two times child vaccinations are recommended by the World Health Organization (WHO) which are available to households; free of cost, as they are funded by the government of Pakistan. These vaccinations make children fully immunized. The vaccines contain: I dose of BCG, 3 doses of DPT, 4 doses of Polio, 2 doses of Measles, 3 doses of Pentavalent, 3 doses of Pneumococcal, 3 doses of Hepatitis (B1, B2, B3) and 3 doses of HIB (1, 2, 3). PDHS 2017-18 contains information on the immunization of children (under 5 years) for all these vaccinations. The child immunization status is taken in ordered form and categorized as no immunization coverage, 
less immunization coverage, moderate immunization coverage, high immunization coverage and full immunization coverage. Additive indexing technique is used to generate vaccination status of children and the value of index ranging from 0 to 22. To make it a categorical variable, zero is assigned to no vaccination where additive index value is zero; 1 to less vaccination status whereas additive index value is 1 to $7 ; 2$ to moderate vaccination status where additive index values are 8 to $14 ; 3$ to high vaccination status where additive index value is 15 to 21 ; and 4 to full vaccination status where children receive all twenty two doses of vaccinations and the additive index value is 22 .

\subsubsection{Measuring Women Employment}

Women's employment status is taken as binary i.e. employed or not.

\subsubsection{Wealth Index}

The wealth score is based on a household's asset ownership information. The PDHS survey asks about the household's holding of a diversified group of assets such as TV and vehicle, along with home characteristics like flooring material, type of drinking water source, and bathroom facilities, as well as other wealth-related characteristics. A weight or factor score is applied to each household asset for which data is obtained using principal components analysis. For each asset, a standardized score is assigned to each household, with the score varying depending on whether or not the household owns the asset. Five groups of wealth with an equal group of participants each create the breakpoints that identify wealth quintiles as Lowest, Second, Middle, Fourth, and Highest. (PDHS 017-18).

\subsection{Estimation Technique}

To analyze the effect of mothers' employment on the health care of their children i.e. immunization status, the ordered logistic regression technique is used. The dependent variable (child immunization) is categorical and it is assumed that the order between them is meaningful and the distance between them is arbitrary.

The following is the estimation equation for children's immunization status:

\subsection{Model Specification}

\subsubsection{Functional Form of the Model}

Child Immunization $=\mathrm{f}$ (Child Gender, Birth Order of the Child, Number of Siblings under Age 5, Maternal Education, Maternal Occupation, Maternal Mobile Phone Ownership, Maternal Age, Number of Antenatal Care Visits, Household's Wealth Quintile, Household' Area of Residence)

Econometric Form of the Model

$$
\begin{aligned}
& \text { CHIMMUN }=\beta_{0}+\beta_{1} \text { CHGNDR }+\beta_{2} \text { BORD }+\beta_{3} \text { CHU } 5+\beta_{4} M E D U+\beta_{5} \text { MOCPTN }+ \\
& \beta_{6} \text { PHONE }+\beta_{7} M A G E+\beta_{8} A N C V+\beta_{9} W E A L T H+\beta_{10} A R E A+\varepsilon_{i}
\end{aligned}
$$

Where IMMUN is the estimated score of the ordered logistic model and it is the linear function of all explanatory variables.

\section{Results and Discussion \\ 5.1. Descriptive Analysis}

The qualitative analysis of child immunization is shown in Tables 4 and 5. The number of fully immunized children in the study sample was determined to be 23.36 percent (1388 out 
of 5872). The proportion of children in the lowest income group (poorest families) who obtained full immunization was only $22 \%$, which was the worst among children in other income quintiles. Most completely immunized children (about 50\%) have uneducated mothers, while 40.72 percent of mothers with access to media (cell phone) had children who have received all vaccination doses recommended. Only $12 \%$ of fully immunized children have a working mother, which is an extremely low percentage in comparison to children who do not have a working mother. Furthermore, in regression analysis, all of the selected were shown to be significant, excluding the wealth index and the type of residence. Table 6 provides a detailed summary of these and other aspects.

Table 4: Characteristics of study participants (women with their child) in Pakistan (2018 DHS)

\begin{tabular}{|c|c|c|c|}
\hline Variables & Categories & Frequency & Percentage \\
\hline \multirow{5}{*}{$\begin{array}{c}\text { Child Immunization } \\
\text { Coverage }\end{array}$} & No Immunization & 432 & 7.4 \\
\hline & Less & 1184 & 20.1 \\
\hline & Moderate & 772 & 13.1 \\
\hline & High & 2096 & 35.6 \\
\hline & $\begin{array}{l}\text { Full Immunization } \\
\text { Coverage }\end{array}$ & 1388 & 23.6 \\
\hline \multirow[t]{2}{*}{ Gender of Child } & Male & 2986 & 50.9 \\
\hline & Female & 2886 & 49.1 \\
\hline \multirow[t]{2}{*}{ Birth Order of Child } & $\leq 2$ & 2560 & 43.6 \\
\hline & $>2$ & 3312 & 56.4 \\
\hline \multirow{2}{*}{$\begin{array}{l}\text { No. of Children age } 5 \text { and } \\
\text { below }\end{array}$} & $\leq 5$ & 5635 & 96 \\
\hline & $>5$ & 237 & 4 \\
\hline \multirow[t]{2}{*}{ Mother's Occupation } & Not Working & 5162 & 87.9 \\
\hline & Working & 710 & 12.2 \\
\hline \multirow{4}{*}{ Mother's Education } & No education & 2883 & 49.1 \\
\hline & Primary & 779 & 13.3 \\
\hline & Secondary & 1278 & 21.8 \\
\hline & Higher & 932 & 15.9 \\
\hline \multirow{2}{*}{$\begin{array}{l}\text { Mother Having Own Mobile } \\
\text { Phone }\end{array}$} & No & 3481 & 59.3 \\
\hline & Yes & 2391 & 40.7 \\
\hline \multirow{3}{*}{ Mother's Age } & Age $<20$ & 274 & 4.6 \\
\hline & $20-34$ & 4550 & 77.5 \\
\hline & $35-49$ & 1048 & 17.9 \\
\hline \multirow{5}{*}{ No. of Antenatal care visits } & No Antenatal care visit & 831 & 14.2 \\
\hline & ANC 1 & 455 & 7.7 \\
\hline & ANC 2 & 797 & 13.6 \\
\hline & ANC 3 & 831 & 14.2 \\
\hline & ANC 4 \&above & 2758 & 50.3 \\
\hline \multirow{5}{*}{ Wealth Index } & Poorest & 1292 & 22.0 \\
\hline & Poorer & 1274 & 21.7 \\
\hline & Middle & 1163 & 19.8 \\
\hline & Richer & 1042 & 17.7 \\
\hline & Richest & 1101 & 18.8 \\
\hline Area of Residence & Urban & 2661 & 45.3 \\
\hline
\end{tabular}


Table 5: Cross tabulation for child Immunization

\begin{tabular}{ccccccc}
\hline $\begin{array}{c}\text { Child } \\
\text { Immunization }\end{array}$ & $\begin{array}{c}\text { No } \\
\text { Immunization }\end{array}$ & $\begin{array}{c}\text { Less } \\
\text { Immunization }\end{array}$ & $\begin{array}{c}\text { Moderate } \\
\text { Immunization }\end{array}$ & $\begin{array}{c}\text { High } \\
\text { Immunization }\end{array}$ & $\begin{array}{c}\text { Full } \\
\text { Immunization }\end{array}$ & Total \\
\hline $\begin{array}{c}\text { Mother } \\
\text { Occupation }\end{array}$ & & & & & & \\
\hline Not Working & 385 & 1043 & 686 & 1843 & 1205 & $\begin{array}{c}5162 \\
(87.9)\end{array}$ \\
\hline Working & 47 & 141 & 86 & 253 & 183 & $\begin{array}{c}710 \\
(12.2)\end{array}$ \\
\hline Mother & & & & & &
\end{tabular}

Education

\begin{tabular}{ccccccc}
\hline No Education & 344 & 881 & 361 & 820 & 477 & $\begin{array}{c}2883 \\
(49.10)\end{array}$ \\
\hline Primary & 37 & 109 & 116 & 287 & 230 & $\begin{array}{c}779 \\
(13.27)\end{array}$ \\
\hline Secondary & 30 & 117 & 174 & 577 & 380 & $\begin{array}{c}1278 \\
(21.76)\end{array}$ \\
\hline Higher & 21 & 77 & 121 & 412 & 301 & $\begin{array}{c}932 \\
(15.87)\end{array}$ \\
\hline
\end{tabular}

No. of

Antenatal

Care Visits

\begin{tabular}{|c|c|c|c|c|c|c|}
\hline No ANCV & 156 & 305 & 79 & 181 & 110 & $\begin{array}{c}831 \\
(14.15)\end{array}$ \\
\hline ANCV1 & 45 & 125 & 54 & 143 & 88 & $\begin{array}{c}455 \\
(7.75)\end{array}$ \\
\hline ANCV2 & 66 & 197 & 128 & 255 & 151 & $\begin{array}{c}797 \\
(13.57)\end{array}$ \\
\hline ANCV3 & 59 & 165 & 104 & 312 & 191 & $\begin{array}{c}831 \\
(14.15)\end{array}$ \\
\hline $\begin{array}{l}\text { ANCV4 } \\
\& \text { Above }\end{array}$ & 106 & 392 & 407 & 1205 & 848 & $\begin{array}{c}2958 \\
(50.37)\end{array}$ \\
\hline \multicolumn{7}{|l|}{ Wealth Index } \\
\hline Poorest & 183 & 440 & 167 & 340 & 162 & $\begin{array}{c}1292 \\
(22.00)\end{array}$ \\
\hline Poorer & 121 & 299 & 155 & 420 & 279 & $\begin{array}{c}1274 \\
(21.70)\end{array}$ \\
\hline Middle & 58 & 208 & 148 & 458 & 291 & $\begin{array}{c}1163 \\
(19.81)\end{array}$ \\
\hline Richer & 49 & 136 & 156 & 397 & 304 & $\begin{array}{c}1042 \\
(17.75)\end{array}$ \\
\hline Richest & 21 & 101 & 146 & 481 & 352 & $\begin{array}{c}1101 \\
(18.75)\end{array}$ \\
\hline
\end{tabular}




\begin{tabular}{|c|c|c|c|c|c|c|}
\hline Mother Age & & & & & & \\
\hline Age $<20$ & 38 & 62 & 61 & 84 & 29 & $\begin{array}{c}274 \\
(4.67)\end{array}$ \\
\hline $20-34$ & 311 & 889 & 611 & 1663 & 1076 & $\begin{array}{c}4550 \\
(77.49)\end{array}$ \\
\hline $35-49$ & 84 & 233 & 100 & 349 & 283 & $\begin{array}{c}1048 \\
(17.85)\end{array}$ \\
\hline \multicolumn{7}{|l|}{$\begin{array}{c}\text { Child Birth } \\
\text { Order }\end{array}$} \\
\hline $\begin{array}{c}\text { Birth Order } \leq \\
2\end{array}$ & 155 & 453 & 364 & 950 & 638 & $\begin{array}{c}2560 \\
(43.60)\end{array}$ \\
\hline $\begin{array}{c}\text { Birth Order }> \\
2\end{array}$ & 277 & 731 & 408 & 1146 & 750 & $\begin{array}{c}3312 \\
(56.40)\end{array}$ \\
\hline \multicolumn{7}{|l|}{$\begin{array}{l}\text { Number of } \\
\text { Children Age } \\
\text { Five And } \\
\text { Below }\end{array}$} \\
\hline Children $\leq 5$ & 406 & 1118 & 740 & 2033 & 1338 & $\begin{array}{c}5635 \\
(95.96)\end{array}$ \\
\hline Children $>5$ & 26 & 66 & 32 & 63 & 50 & $\begin{array}{c}237 \\
(4.04)\end{array}$ \\
\hline \multicolumn{7}{|l|}{$\begin{array}{l}\text { Type of Place } \\
\text { of Residence }\end{array}$} \\
\hline Urban & 164 & 372 & 370 & 1061 & 694 & $\begin{array}{c}2661 \\
(45.32)\end{array}$ \\
\hline Rural & 268 & 812 & 402 & 1035 & 694 & $\begin{array}{c}3211 \\
(54.68)\end{array}$ \\
\hline \multicolumn{7}{|l|}{ Child Gender } \\
\hline Male & 214 & 577 & 375 & 1101 & 719 & $\begin{array}{c}2986 \\
(50.85) \\
\end{array}$ \\
\hline Female & 218 & 607 & 397 & 995 & 669 & $\begin{array}{c}2886 \\
(49.15) \\
\end{array}$ \\
\hline \multicolumn{7}{|l|}{$\begin{array}{l}\text { Mother Own a } \\
\text { Mobile Phone }\end{array}$} \\
\hline No & 350 & 905 & 464 & 1097 & 665 & $\begin{array}{c}3481 \\
(59.28)\end{array}$ \\
\hline Yes & 82 & 279 & 308 & 999 & 723 & $\begin{array}{c}2391 \\
(40.72) \\
\end{array}$ \\
\hline Total & $\begin{array}{c}432 \\
(7.36) \\
\end{array}$ & $\begin{array}{c}1184 \\
(20.16) \\
\end{array}$ & $\begin{array}{c}772 \\
(13.15) \\
\end{array}$ & $\begin{array}{c}2096 \\
(35.69) \\
\end{array}$ & $\begin{array}{c}1388 \\
(23.64) \\
\end{array}$ & $\begin{array}{l}5872 \\
(100) \\
\end{array}$ \\
\hline
\end{tabular}

\subsection{Ordered Logistic Regression Analysis (OLR)}

Table 7 shows the findings of Ordered Logistic Regression. According to the results, the probability of a child being fully immunized reduces as a mother's employment rises (a child 
whose mothers are employed, there are 18 percent fewer chances to be fully vaccinated in comparison of children with unemployed mothers). Further, the results of wealth index and type of place of residence also showed an insignificant impact on child immunization. Only the lowest (poorest) quintile showed a significant and negative impact on child immunization. Male children were 8 percent more chances than female children to be fully vaccinated.

Female education has a positive effect on the vaccination uptake of her children; for example, a mother with higher education has more chances for her children to be fully immunized. The number of children under age five and birth order of children has a significant negative impact on child immunization while antenatal care visits will $7 \%$ increase child immunization.

Table 6: Results of Ordered Logistic Regression for Immunization of Children

\begin{tabular}{|c|c|c|c|c|}
\hline Variables & Coefficient & Significance & S.E. & $\operatorname{Exp}(B)$ \\
\hline \multicolumn{5}{|l|}{$\begin{array}{l}\text { MOCCU (Mother Occupation } \\
\text { Binary) }\end{array}$} \\
\hline No & -0.187 & $0.012^{* *}$ & 0.074 & 0.829 \\
\hline Yes & $\begin{array}{l}\text { Reference } \\
\text { category }\end{array}$ & - & - & 1.00 \\
\hline $\begin{array}{l}\text { NCHU (Number of Children Age } 5 \\
\text { and Below) }\end{array}$ & -0.076 & $0.000^{*}$ & 0.016 & 0.927 \\
\hline BORD (Birth order) & -0.078 & $0.000^{*}$ & 0.016 & 0.925 \\
\hline ANCV (Antenatal Care Visits) & 0.070 & $0.000^{*}$ & 0.009 & 1.073 \\
\hline MAGE (Mother Age) & 0.053 & $0.005^{*}$ & 0.000 & 1.055 \\
\hline \multicolumn{5}{|l|}{ MEDU (Mother Education) } \\
\hline No education & -0.501 & $0.000^{*}$ & 0.090 & 0.606 \\
\hline Primary & 0.184 & $0.060^{* * *}$ & 0.097 & 1.202 \\
\hline Secondary & 0.227 & $0.005^{*}$ & 0.815 & 1.255 \\
\hline Higher & $\begin{array}{l}\text { Reference } \\
\text { category }\end{array}$ & - & - & 1.00 \\
\hline \multicolumn{5}{|l|}{$\begin{array}{l}\text { MOWN(Mother Own a Mobile } \\
\text { Phone) }\end{array}$} \\
\hline No & -0.232 & $0.000^{*}$ & 0.056 & 0.793 \\
\hline Yes & $\begin{array}{l}\text { Reference } \\
\text { category }\end{array}$ & - & - & 1.00 \\
\hline \multicolumn{5}{|l|}{ WINDX (Wealth Index) } \\
\hline Poorest & -0.626 & $0.000^{*}$ & 0.105 & 0.535 \\
\hline Poorer & -0.149 & 0.115 & 0.094 & 0.862 \\
\hline Middle & -0.017 & 0.842 & 0.085 & 0.983 \\
\hline Richer & -0.017 & 0.838 & 0.081 & 0.983 \\
\hline Richest & $\begin{array}{l}\text { Reference } \\
\text { category }\end{array}$ & - & - & 1.00 \\
\hline \multicolumn{5}{|l|}{ CGEN (Child Gender) } \\
\hline Male & 0.083 & $0.082^{* * *}$ & 0.047 & 1.086 \\
\hline Female & $\begin{array}{l}\text { Reference } \\
\text { category }\end{array}$ & - & - & 1.00 \\
\hline \multicolumn{5}{|l|}{ PRES (Type of Place of Residence) } \\
\hline Urban & -0.084 & 0.129 & 0.055 & 0.919 \\
\hline Rural & $\begin{array}{l}\text { Reference } \\
\text { category }\end{array}$ & - & - & 1.00 \\
\hline
\end{tabular}


ChiSq $($ Model 1) $=963.870 ;$ ChiSq $($ Model 2$)=978.976 ; \mathrm{N}=5872$

$*, * *$ and $* * *$ represents significant at the level of 1,5 and $10 \%$ respectively

\subsubsection{Individual Characteristics:}

The gender of the child was included in the individual characteristics to see the impact of the mother's work on the immunization status of their children. The gender of the child was taken to determine the immunization status of children when their mothers work. According to regression results, male children are preferred to female children in their vaccination uptake i.e. male children are found to be more chances for vaccination uptake than female children (Biswas et al., 2001).

The birth order of children refers to the order in which they were born. The findings reveal that as the birth order increases, the likelihood of being immunized children decreases. It is hypothesized that a higher birth-order child has a lesser probability to have health care in the form of immunization; based on assumption i.e. larger number of children decreases the marginal satisfaction of parents/mothers to have children. Moreover, due to time and resource constraints, it becomes difficult for a household to provide health care to a large number of children.

The number of children aged five and under was included in the study to determine the effect of maternal employment on the vaccination uptake of their children. Children under the age of five are less likely to be immunized, according to the findings.

\subsubsection{Mother's Characteristics:}

According to regression results, the children of working mothers are found to be less likely to be immunized as compared to children of not working mothers. It could explain that the majority of employed women are self-employed or living on a subsistence level of income or belongs to poor families. Women's illiteracy, lack of professional education, and technological know-how are all indicators of low immunization of their children. In a societal context, it may be explained that the household's main earning hand is believed to be a male headed household, but women are forced into the labor market when the household's fundamental necessities are not being met because most of the employed females belong to poor or low income families.

Similarly, the nature of the mother's employment may have a different impact on child health care. Mothers working in the agricultural sector and clerical work have a positive and significant effect on child immunization while mothers in manual work have an insignificant impact on child immunization as compared to professional working.

The role of mothers' education in their children's vaccination uptake has also been incorporated into the analysis. Children with uneducated mothers are less likely to be vaccinated, according to findings. Increased levels of maternal education demonstrated to have a positive impact on the outcome of child immunization. It further explains the fact that educated women are more aware of the importance of child immunization (Smith, et al., 2003; Wamani, et. al., 2004; Khan \& Aslam, 2001; and Streatfield et al., 1990).

Antenatal care visits increase the probability of children being fully immunized while having access to media may decrease the immunization status of children. It may be conferred that antenatal care has spill-over effects on child health care and it is likely through the transfer of information and knowledge about child health care at the time of prenatal consultation. 


\subsubsection{Socioeconomic Characteristics:}

To investigate the effect of household socioeconomic status on child immunization, we employed the wealth index (Wagstaff and Watanabe, 2000; Oakes and Rossi, 2003; Fotso and Kaute-Defo, 2006). The PDHS wealth index is based on two basic ideas for determining economic status: 1) the distribution of health services among the poor, and 2) the ability to pay for health care. In comparison to income or expenditure indexes, wealth indexes can better describe the allocation of health services to the poor (Rutstein, et. al. 2004; khan \& Raza 2014; khan \& Raza 2014). According to Biswas et al. (2001), children are fully immunized if the family's economic situation is stable. The regression results of the current study for wealth index showed an insignificant impact on vaccination uptake of their children. The results demonstrate, as immunization of children is free of cost, so the resource constraint becomes ineffective for the households.

\subsubsection{Regional Characteristics:}

The geographic locality of households i.e. urban and rural locality has an impact on the accessibility of healthcare services. In the analysis, variables of household locality (urban/rural) have been included as qualitative variables. It is theoretically assumed that urban children have more chances for health care as compared to rural areas. Econometric results showed an insignificant impact on child vaccination uptake. It explains that if resources are provided free of cost, the resource constraint becomes ineffective for the households.

\section{Conclusion and Policy Recommendation:}

The study provides evidence on child healthcare determinants in Pakistan. There is great concern in low- and middle-income economies, women's employment plays a significant role in child health care. The main objective of the current study is to see the impact of mothers' employment on child health care in Pakistan. According to the empirical results, it is concluded that in child health care, women's employment plays a significant role. If a woman is employed and belongs to a household of lower socioeconomic status (poorest quintile), the probability of child health-care decreases. It is suggested that to improve child health care in Pakistan, women's employment should be improved. To implement this goal, there is a need to formulate policies to eliminate power inequalities between males and females. It may be attained by the implementation of inheritance law and the basic human and woman rights, enabling the woman to attain new resources and reduction of gender discrimination laws. Social organizations and media can play important role in the decision making of employed mothers, by spreading information to households.

There are some other important results related to policy implications. Gender discrimination still exists in child health-care. This discrimination may be linked with women in coming years when these children (children under study are below the age of 5 years) will become adults. Children discriminated today in food, nutrition, and education distribution would face the same situation when they become adults, which they have faced in their childhood. It will develop the psyche of gender discrimination in these children in their grown-up age, and they will behave in the same manner as in their adulthood. Therefore, the interventions for the elimination of gender discrimination in child healthcare ought to be made with a focus on women's employment and the intergenerational detrimental effects of gender discrimination. The antenatal care to be taken by women during pregnancy is a complement of child healthcare in form of child vaccination during the first 12 months of childhood. It creates a series of vaccination. The notion leads to consider the antenatal-care visits as the focal point in the program and policies about women and child health care. Children from poor households 
suffer a greater risk of poor healthcare. Poverty elimination should be an agenda of policymakers in Pakistan. Mothers' education has also shown an impressive effect on child health care as it should be focused on the policy to improve child health care in Pakistan.

\section{References:}

Acharya, P., Kismul, H., Mapatano, M. A., \& Hatløy, A. (2018). Individual-And Community-Level Determinants of Child Immunization in the Democratic Republic of Congo: A Multilevel Analysis. PloS one, 13(8), e0202742.

Andersen, R., \& Newman, J. F. (1973). Societal and Individual Determinants of Medical Care Utilization in the United States. The Milbank Memorial Fund Quarterly. Health and Society, 95-124.

Andersen, R., \& Newman, J. F. (2005). Societal and individual determinants of medical care utilization in the United States. The Milbank Quarterly, 83(4), 1-28.

Asif, A. M., Akbar, M., Tahir, M. R., \& Arshad, I. A. (2019). Role of Maternal Education and Vaccination Coverage: Evidence from Pakistan Demographic and Health Survey. Asia Pacific Journal of Public Health, 31(8), 679-688.

Biswas, S.C., M.A. Darda \& M.F. Alam, (2001). Factors Affecting Childhood Immunization in Bangladesh. Pakistan Development Review, 40(1): 57-70.

Boyle, E. H., Gangestad, G., King, M. L., \& Sarkar, S. (2018). Women's Labor Force Participation and Breastfeeding in Three African Countries.

Brauner-Otto, S., Baird, S., \& Ghimire, D. (2019). Maternal Employment and Child Health in Nepal: The Importance of Job Type and Timing across the Child's First Five Years. Social Science \& Medicine, 224, 94-105.

Burroway, R. (2017). Are All Jobs Created Equal? A Cross-National Analysis of Women's Employment and Child Malnutrition in Developing Countries. Social Science Research, 67, 1-13.

Crepinsek, M., \& Burstein, N. (2004). Maternal Employment and Children's Nutrition Volume I: Diet Quality and the Role of the CACFP. Washington, DC: Economic Research Service; 2004.

Donabedian, A. (2005). Evaluating the Quality of Medical Care. The Milbank Quarterly, 83(4), 691.

Duclos, P., Okwo-Bele, J., Gacic-Dobo, M., \& Cherian, T. (2009). Global Immunization: Status, Progress, Challenges and Future (Opinion). BMC International Health and Human Rights, 9(1): 1.

Fotso, J. \& Kaute-Defo, B. (2006). Household and Community-Socioeconomic Influences on Early Childhood Malnutrition in Africa. Journal of Biosocial Science, 38(3): 289-313.

Gaina, A., Sekine, M., Chandola, T., Marmot, M., \& Kagamimori, S. (2009). Mother Employment Status and Nutritional Patterns in Japanese Junior High Schoolchildren. International Journal of Obesity, 33(7), 753-757.

Garti, H., Ali, Z., \&Garti, H. A. (2018). Maternal Daily Work Hours Affect Nutritional Status of Children in Northern Ghana. Nutrire, 43(1), 16.

Grossman, M. (1972). On the Concept of Health Capital and the Demand for Health. Journal of Political economy, 80(2), 223-255.

Hindmarsh, G., Llewellyn, G., \& Emerson, E. (2017). The Social-Emotional Well-Being of Children of Mothers with Intellectual Impairment: A Population-Based Analysis. Journal of Applied Research in Intellectual Disabilities, 30(3), 469-481.

Imran, H., Raja, D., Grassly, N. C., Wadood, M. Z., Safdar, R. M., \& O’Reilly, K. M. (2018). Routine Immunization in Pakistan: Comparison of Multiple Data Sources And 
Identification Of Factors Associated With Vaccination. International health, 10(2), 84-91.

JAMAL, H. (2018). Exploring the Relationship between Mother's Empowerment and Child Nutritional Status: An Evidence from Pakistan. Pakistan Journal of Applied Economics, 28(2), 189-211.

Kabir, A. (2016). Feeding Practices and Nutritional Status of Extreme Poor Young Children in Families of Working Mothers in Slums of Dhaka. Swiss Agency for Department and Co-Operation SDC.

Khan, M. T., Zaheer, S., \&Shafique, K. (2017). Maternal Education, Empowerment, Economic Status and Child Polio Vaccination Uptake In Pakistan: A Population Based Cross Sectional Study. BMJ open, 7(3), e013853.

Khan, R. E. A., \& Raza, M. A. (2014). Nutritional Status of Children in Bangladesh: Measuring Composite Index of Anthropometric Failure (CIAF) and Its Determinants.

Khan, R.E.A. \& Raza, M. A. (2014). Child Malnutrition in Developing Economies: A Case Study of Bangladesh. Quality \& Quantity, 48(3): 1389-1408

Khan, R.E.A., \& Aslam, I. (2017). Child Immunization in Pakistan: Socio-Institutional and Regional Aspects, Asian Journal of Economic Modeling, 5(1): 49-56.

Khan, R.E.A., \& Raza, M. A. (2013). Maternal Health-Care in India: The Case of Tetanus Toxoid Vaccination. Asian Development Policy Review, 1(1): 1-14.

Kim, J. (2020). Relations among Maternal Employment, Depressive Symptoms, Breastfeeding Duration, and Body Mass Index Trajectories in Early Childhood. Journal of the Korean Society of Maternal and Child Health,24(2), 75-84.

Komatsu, H., Malapit, H. J. L., \& Theis, S. (2018). Does Women's Time in Domestic Work and Agriculture Affect Women's and Children's Dietary Diversity? Evidence from Bangladesh, Nepal, Cambodia, Ghana, and Mozambique. Food Policy, 79, 256-270.

Lavy, V., Strauss, J., Thomas, D., \& De Vreyer, P. (1996). Quality of Health Care, Survival and Health Outcomes in Ghana. Journal of Health Economics, 15(3), 333-357.

Lee, H. Y., Oh, J., Heo, J., Abraha, A., Perkins, J. M., Lee, J. K., \& Subramanian, S. V. (2019). Association between Maternal Literacy and Child Vaccination in Ethiopia and Southeastern India and the Moderating Role of Health Workers: A Multilevel Regression Analysis of the Young Lives Study. Global Health Action, 12(1), 1581467.

Mindlin, M., Jenkins, R., \& Law, C. (2009). Maternal Employment and Indicators of Child Health: A Systematic Review in Pre-School Children in OECD Countries. Journal of Epidemiology \& Community Health, 63(5), 340-350.

Mosley, W. H., \& Chen, L. C. (1984). An Analytical Framework for the Study of Child Survival in Developing Countries. Population and Development Review, 10, 25-45.

Nankinga, O., Kwagala, B., \& Walakira, E. J. (2019). Maternal Employment and Child Nutritional Status in Uganda. PloS one, 14(12), e0226720.

Oakes, J.M. \& Rossi, P.H. (2003). The Measurement of SES in Health Research: Current Practices and Steps towards a New Approach. Social Science \& Medicine, 56(4): 769784.

Oddo, V. M., \& Ickes, S. B. (2018). Maternal Employment in Low-And Middle-Income Countries Is Associated with Improved Infant and Young Child Feeding. The American journal of clinical nutrition, 107(3), 335-344.

Onah, M. N. (2020). Approaches to Understanding and Measuring Women's Empowerment and Its Relationship with Women's and Children's Dietary Diversity in Sub-Saharan Africa.

Pakistan Bureau of Statistics (PBS). Provisional Summary Results of 6th Population and Housing Census-2017. 
Pande, R.P. (2003). Selective Gender Differences in Childhood Nutrition and Immunization in Rural India: The Role of Siblings. Demography, 40(3): 395-418.

Potocka, A., \&Jacukowicz, A. (2017). Differences in Nutritional Status of Preschool Children in the Context of the Maternal Social Characteristics. International journal of occupational medicine and environmental health, 30(5), 811.

Rao, N., Gazdar, H., Chanchani, D., \& Ibrahim, M. (2019). Women's Agricultural Work and Nutrition in South Asia: From Pathways to a Cross-Disciplinary, Grounded Analytical Framework. Food Policy, 82, 50-62.

Rashad, A. S., \& Sharaf, M. F. (2019). Does Maternal Employment Affect Child Nutrition Status? New Evidence from Egypt. Oxford Development Studies, 47(1), 48-62.

Robert, E., Dramaix, M., \& Swennen, B. (2014). Vaccination Coverage for Infants: CrossSectional Studies in Two Regions of Belgium. BioMed Research International, 2014.

Rutstein, S.O. and Kiersten, J. (2004). The DHS Wealth Index, DHS Comparative Report No. 6, Calverton, Maryland, USA: ORC Macro.

Smith, L. C., Ramakrishnan, U., Ndiaye, A. L., Hadad, \& Martorell, R. (2003). The Importance of Women's Status for Child Nutrition in Developing Countries, Research Report 131, International Food Policy Research Institute, Washington, D.C.

Streatfield, K., Singarimbun M., \& Diamond, L. (1990). Maternal Education and Child Immunization. Demography, 27(3): 447-455.

Wagstaff, A. \& Watanabe, N. (2000). Socioeconomic Inequalities in Child Malnutrition in the Developing World. Policy Research Working Paper No. 2434.Washington, DC: The World Bank.

Wamani, H., Tylleskar, T., Astrom, A. N., Tumwine, J. K., \& Peterson, S. (2004). Mother's Education but Not Father's Education, Household Assets and Land Ownership Is the Best Predictor of Child Health Inequalities in Rural Uganda. International Journal for Equity in Health, 3(9):1-8.

Wasswa, G. (2019). Essays on Maternal Employment and Child Health Outcomes (Doctoral Dissertation, University of Nottingham).

Yaya, S., Odusina, E. K., Uthman, O. A., \& Bishwajit, G. (2020). What Does Women's Empowerment Have to Do with Malnutrition in Sub-Saharan Africa? Evidence from Demographic and Health Surveys from 30 Countries. Global health research and policy, 5(1), 1-11.

Zaidi, S. M. A., Khowaja, S., Kumar Dharma, V., Khan, A. J., \& Chandir, S. (2014). Coverage, Timeliness, And Determinants of Immunization Completion in Pakistan: Evidence from The Demographic and Health Survey (2006-07). Human vaccines \& immunotherapeutic, 10(6), 1712-1720. 